\title{
Assessment of a multispecies fishery in Senegal, using production models and diversity indices
}

\author{
1 \\ is \\ Didier Gascuel (1) and Frédéric Ménard ${ }^{(2)}$ \\ (1) ENSAR, Unité Halieutique, 65 route de St Brieur, 35042 Rennes Cédex, France. \\ Imail: gascuel@roazhom.inra.fr \\ (2) ORSTOM, Centre de Recherches Océanologiques, BP V18, Abidjan, République de Côte d'Ivoire. \\ Email: menard@cro.orstom.ci
}

Received July 29, 1996; accepted June 6, 1997.

Gascuel D., F. Ménard. Aquat. Living Resour., 1997, 10, 281-288.

\section{Abstract}

Résumé
This paper presents a multispccific approach in order to assess the main demersal resources exploited off Senegal (West-Africa). In absence of reliable data on the actual fishing effort, two series of theoretical fishing effort are estimated, using available species abundance indices from 1971 to 1991. These two series correspond to different hypotheses concerning the trends of fleets' fishing power: an optimistic one and a pessimistic one. For each spccies or taxa, a surplus production model is calculated with landings statistics and effort. The combining of monospecific models provides a multispecific diagnosis. The analysis is completed by the calculation of diversity indices of catches at the equilibrium level, expressed as a function of fishing effort. While considering the uncertainty around this first assessment, we show that Senegalese groundfish resource is globally full or over-exploited, according to the considered hypothesis. Under the pessimistic hypothesis, 9 among the 11 taxa of Pisces were clearly over-exploited, with lishing effort sometimes as much as twice or three times the effort of maximisation $\left(f_{M S Y}\right)$. The situation is very critical for Arius sp., Epinephelus aeneus, Pagellus bellottii and Pomadasys sp. Using the multispecific approach, pessimistic diagnosis indicates a fishing effor nearly twice $\mathrm{f}_{\mathrm{MSY}}$, with a Maximum Sustainable Yield at about $53000 \mathrm{t}$ for the 11 taxa together. Conversely, in 1991, octopus and cuttlefish appeared under-exploited. The diversity analysis shows that an increase in fishing effort would lead to a decrease in catch diversity. This result is interpreted as a sign of fragility in the exploited ecosystem.

Keywords: Stock assessment, surplus production models, multispecies approach, biodiversity, demersal resources, Senegal.

Evaluation d'une pêcherie pluri-spécifique au Sénégal, par l'approche globale et l'utilisation d'indices de diversité.

On présente ici une approche pluri-spécifique, visant à évaluer les principales ressources démersales exploitées au Sénégal. En l'absence de statistiques d'effort de pêche fiables, deux séries d'efforts de pêche théoriques sont estimées à partir des données d'indices d'abondance disponibles (1971-1991). Ces deux séries se rapportent à des hypothèses différentes concernant l'évolution des puissances de pêche des flottilles; elles sont respectivement qualifiées d'optimiste et de pessimiste. Pour chaque espèce ou taxon considéré, un modèle global est ajusté aux données de capture et d'effort. Un diagnostic pluri-spécifique global est estimé par combinaison des diagnostics mono-spécifiques. Cette analyse est complétée par le calcul d'indices de diversité des captures à l'équilibre, exprimés en fonction de l'effort de pêche. Au-delà des incertitudes de cette première évaluation, on montre que les ressources démersales sénégalaises sont dans une situation variant, selon les hypothèses retenues, de la pleine exploitation à une très nette surexploitation. Dans l'hypothèse pessimiste, 9 des 11 espèces ou groupes d'espèces de poissons étudiés seraient nettement surexploités, avec des efforts de pêche parfois double, voire triple de l'effort de "maximisation" $\mathrm{f}_{\text {MSY }}$. La 
situation serait particulièrement dégradéc pour Ariuss sp. (mâchoiron), Epinephelus aenus (thiof), Pupellus bellottii (pageot) et Pomadasys sp. (sompatt). Pour les 11 espéces de poissons considérées, le diagnostic pluri-spécifique indique, dans celte hypothèse pessimiste, un effort presque double du $\mathrm{f}_{\mathrm{MSY}}$ avec une Production Equilibrée Maximale estimée à environ 5300() tonnes. A l'inverse, en 1991, la seiche et le poulpe seraient sous-exploités. On montre également que l'accroissement de l'effort se traduirait par une nette diminution de la diversité des prises. Ce résultat est interprété comme un signe de fragilité de l'écosystème exploité.

Mots-clés : Evaluation des stocks, modèles globaux, approche pluri-spécifique, biodiversité, ressources démorsales, Sénégal.

\section{INTRODUCTION}

As in many African countries, the demersal resource is exploited in Senegal by two separate fleets, a traditional one and an industrial onc. The traditional fleet is composed of several thousand multi-purpose dugouts using a large variety of gear, such as purse-seines, gillnets or handlines. The industrial one is made up of about 160 bottom trawlers. In 1991, the production of demersal specics reached $100000 \mathrm{t}$, with roughly an equal share between fleets (Samba, 1994). Because demersal species are fished, to a large extent, in the same area (Diallo, 1994), we can assume that demersal stocks are common to both fisheries (Fonteneau, 1994). Considering the rapid increase of fishing activity and the levels already reached by the production, the assessment of stocks bccomes a priority, notably underlined by the Symposium "Assessment of resources harvestable by the traditional fishery in Senegal", that was held in Dakar in 1993 (BarryGérard et al., 1994).

In the Senegalese context, the assessment is complicated by two difficulties, which are very common in this kind of fishery: the characteristics of catches, which are composed of a large mix of species, and the absence of reliable statistics on the fishing effort developed by the traditional fleet. Caveriviere and Thiam (1994) presented a preliminary analysis based on a surplus production model using the group of demersal species as a whole. In the meantime, Gascuel and Thiam (1994) estimated abundance indices of the main harvested species, using linear models applied to the catch per unit effort (CPUE) of the trawl fishery for the period 1971-1991. Using those indices, Gascucl (1994a, unpubl. rep.) made a first assessment for a selection of demersal and pelagic species. In the present work, a multispecific approach is proposed for the assessment of Senegalese demersal resource. We believe that the proposed method presents a general interest and can be applied to similar situations in different geographical areas.

A theoretical fishing effort is derived from catch statistics and abundance indices and is used as a proxy of the actual effort applied to the stocks. Monospecific surplus production models are fitted for each of the main taxa or species. In a further step, a multispecies catch curve is estimated by combining the monospecific models. In order to assess the potential effects of fishing activity on the demersal biological structure, we propose and discuss a simple analysis of the diversity of those demersal resources harvested. A Shannon index is computed from the relationships between yiclds at the equilibrium level and fishing effort, as calculated from the surplus production model. Rankabundance diagrams are also presented.

\section{MATERIALS AND METHODS}

Catch data of the industrial fishery for the period 1971 to 1991 come from the CRODT (Centre de Recherches Océanographiques de Dakar-Thiaroye) data base, including Senegalese and foreign trawlers. Caverivière (pers. comm.) provided data from the traditional fishery for the period 1971 to 1980 , and the CRODT data base provided the information for the period 1981 to 1991. Among demersal species, we selected 13 taxa or species (Table 1) on the basis of their significance in terms of economic value and landings volume, and the availability of abundance indices and fisheries statistics. Those selected taxa correspond to eleven Pisces and two mollusks. They represent $76 \%$ of the total demersal landings for the 1981 to 1991 period. Catches of trawling and traditional activities have been summed up per year and per taxon.

Theoretical fishing efforts for the 13 taxa and species were computed from the estimated abundance indices of Gascuel and Thiam (1994) and catch data of fisheries statistics. These efforts were related to year 1991 , leading to a series of multiplicators of effort noted $\mathrm{mf}_{\mathrm{n}}$. Catch of year $n$ can be expressed as:

$$
Y_{n}=q_{n}^{\prime} \cdot m f_{n} \cdot I_{n}
$$

where $\mathrm{q}_{n}^{\prime}$, and $\mathrm{I}_{n}$ are catchability coefficient and abundance index of year $n$, respectively. Let $\mathrm{mf}_{91}=1$ denote the theoretical multiplicator of fishing effort for year 1991. Assuming a constant catchability for each species, the theoretical multiplicator of effort for year $n$ is then given by:

$$
\mathrm{mf}_{n}=\left(\mathrm{Y}_{n} / \mathrm{I}_{n}\right)\left(\mathrm{I}_{91} / \mathrm{Y}_{91}\right)
$$

Aquat. Living Ressur.. Vol. 10, n 5 - 1997 
Table 1. - List of the 13 species or taxa considered in this sludy: scientific, local and common names; total catches in Senegal in 1991 (metric tonnes; data from CRODT - Centre de Recherches Océanographique de Dakar-Thiaroye).

\begin{tabular}{lcc}
\hline Specics or taxa & Local name & Common name \\
\hline Arius sp. & Machoiron & sea cattish \\
Epinephelus aeneus & Thiof & white groupcr \\
Epinephelus sp. + Mycteroperca sp. & Mérous & other groupers \\
Pagellus bellottii & Pageot & red pandora \\
Plectorhynchus mediterraneus & Dorade grise & rubberlip grunt \\
Cynoglossus sp. & Sole langue & tonguesoles \\
Sparus caeruleostictus + Dentex sp. & Pagrc ct Iorade rose & couch's \& red sea bream \\
Pseudupeneus prayensis & Rouget & goatfish \\
Pomadasys jubelini + P. peroteti & Sompatt & 274 \\
Pseudotolithus sp.+Umbrina canariensis & Capitaine+Ombrine & spotted grunts \\
Brotula barbata & Brotule & croakerstcanary drum \\
Octopus vulgaris & Poulpe & bearbed brotule \\
Sepia officinalis & Seiche & octopus \\
\hline
\end{tabular}

Abundance indices are estimated from catch and effort data of industrial fishery only, but refer to the whole Senegal stock of each species or taxon. However, Gascuel and Thiam (1994) discussed different sources of index misestimation. One of them is related to the increasing fishing power of the vessels over the long term. Such a technological improvement as well as the increase in fishermen's experience may affect all kinds of vessels. We thus consider our previous series of fishing effort as an optimistic pattern which can underestimate the increase of the actual fishing pressure. Then a new fishing effort called "pessimistic fishing efforts" is computed by multiplying optimistic fishing effort by a $5 \%$ interannual increasing rate. This $5 \%$ value could reasonably be considered as a maximum estimate of the fishing power potential drift, in such a fishery. It is an empirical limit chosen according to our knowledge of the fishery. We then assume that the actual trend of the fishing effort should be between the two series of optimistic and pessimistic effort.

For each taxon or species, we fitted surplus production models to catch data and series of fishing efforts $\mathrm{mf}_{\mathrm{n}}$ optimistic or pessimistic, using the computer program CLIMPROD (Fréon et al., 1993). CLIMPROD allows the taking into account of exogenous climatic covariates, such as wind index or temperature. However, we just used this program in order to estimate parameters $a, b$ and $c$ for the generalized surplus production model (the Pella and Tomlinson 1969 form) written as CPUE $(\mathrm{mf})=(a+b . m \mathrm{f})^{1 /(c-1)}$, without introducing exogenous covariates. Depending on the estimated value of $c$, Schaefer 1954 form (CPUE(mf) $=a+b . m \mathrm{f})$ or Fox 1970 form $(\mathrm{CPUE}(\mathrm{mf})=a \exp (b$. $m \mathrm{f})$ ) of the surplus production model are also fitted. The effort-averaging method of Fox (1975) is used by the program. Models are fitted by the least-squares method using the Marquardt algorithm. Furthermore, CLIMPROD includes a jackknife validation that allows evaluation of the quality of fit to the data and helps us choosing the final model. Estimated parameters are finally used to compute equilibrium yields for different multiplicators of fishing effort for optimistic and pessimistic cases, respectively.
To analyze the diversity of the main demersal resources harvested, two indices are computed from equilibrium yields of the fished taxa and species considered.

- The Shannon index (Shannon, 1948), also called Shannon and Weaver index, is derived from the theory of information. It can be used in ecological studies as a measure of specific diversity (Margalef, 1958 in Frontier, 1983), and is defined as:

$$
H^{\prime}=-\sum_{i=1}^{\prime} \frac{\mathrm{Ye}_{\mathrm{i}}}{\mathrm{Ye}} \log _{2}\left(\frac{\mathrm{Ye}_{\mathrm{i}}}{\mathrm{Ye}}\right)
$$

where: $S$ is the total number of species or taxa in the harvested demersal community (i.e. the richness's maximum equals 13 in our case), $Y e_{i}$ is the equilibrium yield of taxon or species $i$, and $Y e$ is the global multispecies equilibrium yield for a given multiplicator of fishing effort. The value of the Shannon index varies from 0 (only one species) to $\log _{2} S$ (equal abundance for all species).

- The equitability index $\mathrm{R}$ is independent of species number, and constitutes a measure of species equidistribution (Barbault, 1992).

$$
R=\frac{H^{\prime}}{H_{\max }} \quad \text { where } \quad H_{\max }=\log _{2} S
$$

Rank-abundance diagrams for different levels of fishing effort are also calculated. They describe species distribution in catches (logarithm of equilibrium yields for each species as a function of its rank) and can be interpreted as an index of maturity or regression for the exploited ecosystem (Frontier, 1976).

\section{RESULTS}

Parameter estimates and type of model are presented in Table 2. For groupers, the type of data available allows us to fit models for white grouper Epinephelus aeneus only, on one hand, and for all groupers 
Table 2. - Type of model, parameter estimates, coefficient of detcrmination $\left(\mathrm{R}^{2}\right)$, and jackknife cocfficient of determination (Rjk ${ }^{2}$, for the optimistic and pessimistic model of each taxon or species.

\begin{tabular}{|c|c|c|c|c|c|c|c|}
\hline Species of taxa & Model type & a & $\mathrm{b}$ & c & $\mathrm{R}^{2}$ & $\mathrm{Rjk}^{2}$ & Jackknife \\
\hline $\begin{array}{l}\text { Arias sp. } \\
\text { Epincpholus aeneus } \\
\text { Epin. sp. + Mycter. sp. } \\
\text { Pagellas bellottii } \\
\text { Plectorhynchas m. } \\
\text { Cynoglossus sp. } \\
\text { Spartes } \mathrm{c}+\text { Dentex sp. } \\
\text { Pseadupeneas prayensis } \\
\text { Ponadasys j. + P. peroteti } \\
\text { Pseudot. sp.+llmbrina } \\
\text { Brotula barbata } \\
\text { Octopus valgaris } \\
\text { Sepia officinalis }\end{array}$ & $\begin{array}{l}\text { Gencralized } \\
\text { Schatefer } \\
\text { Generalized } \\
\text { Schaefer } \\
\text { Fox } \\
\text { Schacfer } \\
\text { Schaefer } \\
\text { Schacfer } \\
\text { Schaefer } \\
\text { Schacfer } \\
\text { Fox } \\
\text { linear } \\
\text { linear }\end{array}$ & $\begin{array}{r}928 \\
9492 \\
27.8 \\
24588 \\
5341 \\
8661 \\
12408 \\
3257 \\
11791 \\
9632 \\
4547 \\
1450(0) \\
8000\end{array}$ & $\begin{array}{r}-772 \\
-7457 \\
-8.63 \\
-17758 \\
-0.86 \\
-4557 \\
-6267 \\
-1304 \\
-2994 \\
-2690 \\
-0.67\end{array}$ & $\begin{array}{l}1.65 \\
1.34\end{array}$ & $\begin{array}{r}88 \\
79 \\
70 \\
23 \\
76 \\
80 \\
53 \\
29 \\
6 \\
28 \\
75\end{array}$ & $\begin{array}{r}83 \\
74 \\
52 \\
7 \\
69 \\
74 \\
34 \\
12 \\
0 \\
16 \\
66\end{array}$ & $\begin{array}{l}\text { good } \\
\text { good } \\
\text { good } \\
\text { bad } \\
\text { good } \\
\text { good } \\
\text { good } \\
\text { bad } \\
\text { bad } \\
\text { bad } \\
\text { good } \\
\text { good } \\
\text { good }\end{array}$ \\
\hline \multicolumn{8}{|l|}{ Pessimistic } \\
\hline
\end{tabular}

together, on the other (including Epinephelus aeneus). Distinction between white grouper and others was performed by subtraction between equilibrium yiclds.

For octopus (O. vulgaris) and cutllefish (Sepia officinalis), fitting surplus production models was not possible: no clear relationship between efforl and CPUE appeared. The development of the harvesting of these species is still recent, especially for octopus for which catch data are available since 1985. We thus assume that CPUE are independent of fishing effort, for present levels of effort $(\mathrm{CPUE}(\mathrm{mf})=a)$. Then catches increase linearly with effort. It is clear that such a relationship, which is the only one we can estimate, is quite unrealistic over a large range of effort. Nevertheless, it can be accepted for levels of fishing effort lower or near the present level.

For some species or taxa, surplus production models do not fit well the data sets (jackknife validation test of CLIMPROD is poor). Under the pessimistic hypothesis, this is the case for Brotula barbata. Under the optimistic one, Pomadasys sp., Pseudupeneus prayensis, Pagellus bellotiti and the taxon including Pseudotolithus sp. and Umbrina canariensis are concerned. However, estimated parameters for these taxa or species are retained further and Figure 1 shows the equilibrium yield effort relationships from the models (generalized, Fox or Schaefer) of all demersal groups studied.
Results can be interpreted by categorizing demersal stocks in 3 categories, on the basis of the Maximum Sustainable Yield (MSY) and $\mathrm{f}_{\mathrm{MSY}}$ estimations: underexploited, fully-exploited or over-exploited. Because of the nature of the model used, octopus and cuttlefish belong to the under-exploilcd category. So does the Pseudotolithus sp, and Umbrina canariensis group, whether the optimistic or pessimistic case is chosen. However, traditional fishery does not harvest Umbrina canariensis and the quality of the fit is weak for these taxa. Epinephelus aeneus, Arius sp. and Pagellus bellottii belong clearly to the over-exploited category. A decreasing effort should lead to a long-term increase of yields. The interpretation is more qualified for other groupers Epinephelus sp., Cynoglossus sp., Pseudupeneus prayensis, Sparus caeruleostictus, Dentex sp., and Plectorhynchus mediterraneus, that appear fully exploited in the optimistic case, although they are over-exploited in the pessimistic case. Brotula barbata also belongs either to the fully-exploited class in the latter case, or to the under-exploited category in the optimistic case. Only Pomadasys sp. stock behaves in two opposite ways, depending on the hypothesis: overexploited in the pessimistic case and under-exploited in the optimistic one. But model validation was poor for the latter case.

Overall, the multispecific diagnosis for the Senegalese demersal resources varies from an overall fully 


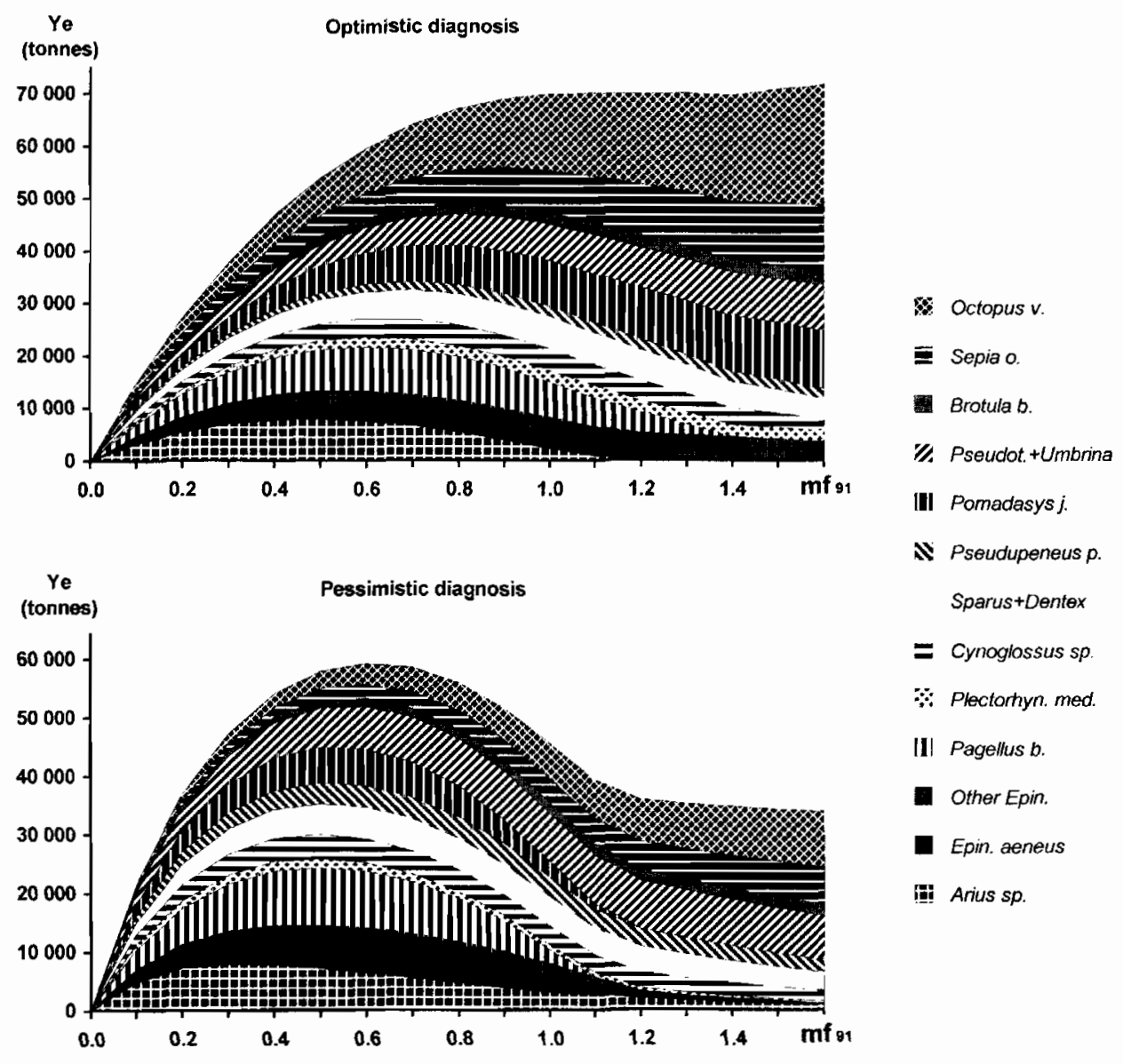

Figure 1. - A multispecies diagnosis for Senegalese demersal resources: equilibrium yields Ye estimated by surpius production models fitted to the main exploited taxa. Optimistic and pessimistic cases refer to the series used as estimations of the multiplicator of the 1991 fishing effort $\mathrm{mf}_{91}$ (sce text).

exploited situation, in the optimistic hypothesis, to a clear over-exploitation in the pessimistic one. Thus, no yield increase could be expected by an increase in the fishing effort. For Pisces, and for the 11 taxa together, production seems to be limited around 50000 tonnes, which is roughly the 1991 yield for those species. Moreover, it seems that there is a substantial risk of decrease in catch if the fishery continues to develop as it did during the last few years. The forecasting of decreased magnitude depends on the chosen diagnosis, optimistic or pessimistic.

No data help us to validate either one or other diagnosis. We can only observe that models fit well for more taxa in the pessimistic case. Moreover, and that is the most important point, pessimistic diagnosis must be considered first in a precautionary approach. In that case, 9 out of 11 taxa of Pisces were clearly overexploited (Table 3). The situation is very critical for Arius sp., Epinephelus aeneus, Pagellus bellottii and Pomadasys sp., with fishing effort as much as twice or three times the effort of maximization $\left(f_{M S Y}\right)$, and present yields that are half the MSY or less. Using the multispecific approach, this pessimistic diagnosis indicates that present fishing effort corresponds to a nonequilibrium situation and is nearly twice $f_{M S Y}$, with a Maximum Sustainable Yield at about 53000 tonnes for the 11 taxa altogether.

Figure 2 illustrates the influence of a modification of the fishing effort on Shannon and equitability indices. The community we are interested in is here strictly defined: it is the main harvested demersal resources of the Senegalese continental shelf. Whether the optimistic or pessimistic case prevails, its diversity should be affected by an increasing fishing effort. Decreasing fishing efforts do not modify strongly the values of the computed indices. However, increasing fishing efforts lead to sharp reductions. Equitability indices show that, independently of species number, an increasing effort leads to a decreasing diversity in the exploited community and, consequently, in the catches' specific composition. 
Table 3. - Diagnosis elements estimaled by surplus production model fitted to cach taxon or species: frshing effort of maximisation $\left(f_{\mathrm{MSY}}\right.$ expressed as a multiplicator of $f_{|q 4|}$ ), Maximum Sustainable Yield (in metric tonnes), and present equilibrium yields Ye $199 \mid$ to MSY ratio. The total diagnosis includes Sepia and Octopus. * refers to diagnosis which are not validated by Jacknife test.

\begin{tabular}{|c|c|c|c|c|c|c|}
\hline Species or taxa & \multicolumn{3}{|c|}{ Optimistic diagnosis } & \multicolumn{3}{|c|}{ Pessimistic diagnosis } \\
\hline Ariuss sp. & 0.47 & 8100 & 0.29 & 0.33 & 8000 & 0.39 \\
\hline Epin. sp. + Mycter. & 0.82 & 6100 & 0.97 & 0.63 & 7700 & 0.64 \\
\hline Pagelluts $b$. & $0.69 *$ & $8500)^{*}$ & $0.80 *$ & 0.53 & 9900 & 0.23 \\
\hline Plectorhinchus m. & 1.16 & 2.300 & 0.99 & 0.38 & 1600 & 0.50 \\
\hline Pseudup.p. & $1.25^{*}$ & $2000^{*}$ & $0.96^{*}$ & 0.68 & 3700 & 0.91 \\
\hline Pontadasys $j$. & $1.97^{*}$ & $11600 \%$ & $0.76^{*}$ & 0.57 & 6200 & 0.44 \\
\hline Pseudot.+Umhrina & $1.79 *$ & $8600^{*}$ & $0.81 *$ & 1.04 & 8300 & 1.00 \\
\hline Brotula b. & 1.49 & 2500 & 0.93 & $1.54 *$ & $2000^{*}$ & $0.92^{*}$ \\
\hline TOTAL & 1.1 & $70(00)$ & 1.0 & 0.63 & 6000() & 0.77 \\
\hline Total fish & 0.8 & 50000 & 1.0 & 0.57 & $5300 \%$ & 0.67 \\
\hline
\end{tabular}

Figure 3 presents rank-abundance diagrams for 3 fishing effort levels: the current one and a decrease or increase of $50 \%$ of the 1991 value. It shows that the least equitable distribution is obtained with the increas-
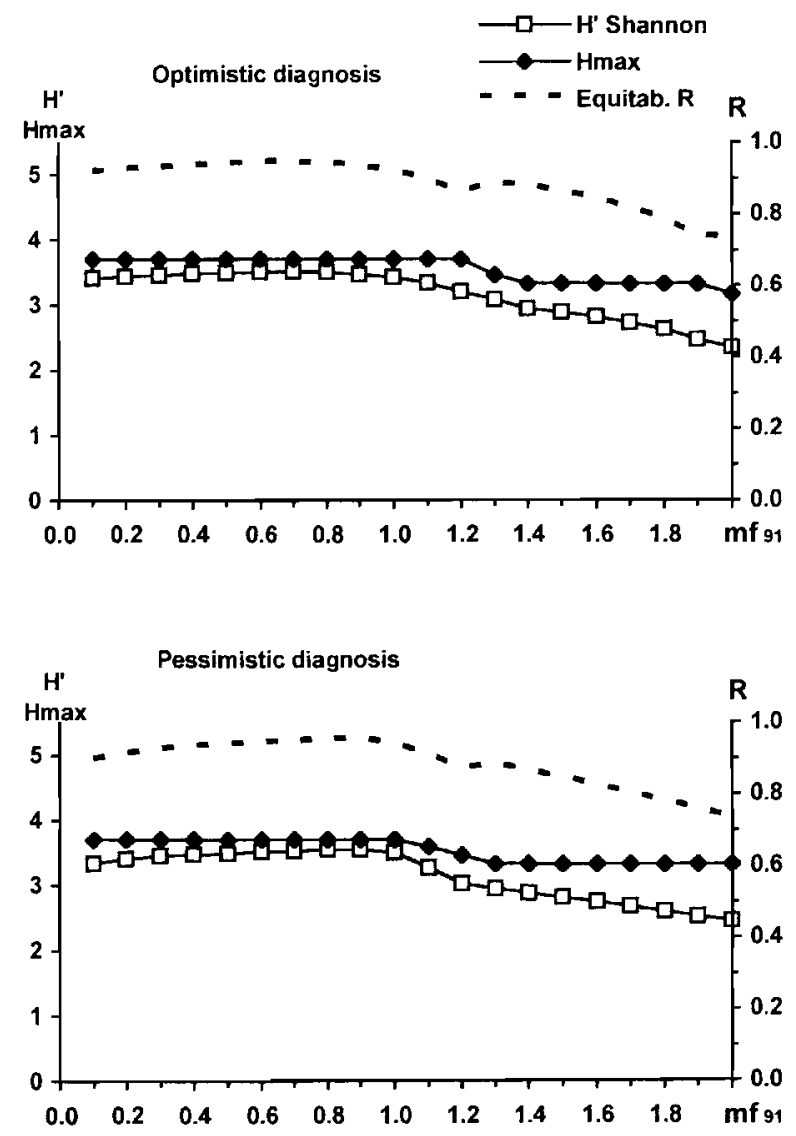

Figure 2. - Indices of the catch diversity as functions of the optimistic and pessimistic fishing efforts: Shannon $\left(H^{\prime}\right)$ and cquitability $(R)$ indices and the maximum entropy $\left(\mathrm{H}_{\text {triax }}\right)$. ing fishing effort pattern: the curve decreases fast, with a stronger trend than in the other cases. Sudden jumps correspond to the disappearance of species in demersal catches: Arius sp. and Epinephelus aeneus in the optimistic case at $\mathrm{mf}=1.3$, for instance

\section{DISCUSSION}

As often in stock assessment studies, many underlying hypotheses are assumed in our approach. The most important one is probably that only Senegalese data were used, although natural limits of these stocks could exceed the Senegal Exclusive Economical Zone (EEZ): the white grouper is an example of a stock divided between Senegal and Mauritania.

Strong assumptions concern also the use of the surplus production model. Firstly, it does not allow the drift of the exploitation pattern to be taken into account. Such a drift is likely to occur in a multifleet fishery, and could hide a damaged stock level. In the case of Senegalese resources, fishery changes in term of fleets and of fishing strategies have been widely studied (see for example Laloë and Samba, 1991). On the other hand, no assessment by age-structured model, which are the only ones able to take account of changes in exploitation pattern, has be done up to now (Gascuel, 1994b). Only Pagellus bellottii has been assessed by these methods (Maury, 1994); this diagnosis confirms a strong over-exploitation.

Furthermore, surplus production models need fishing effort estimations, which are often not reliable for some fleets in the fisheries. In our approach, theoretical fishing effort computed from abundance indices are considered as a proxy of the actual effort applied to the stocks. The abundance indices are computed by Gascuel and Thiam (1994) from the industrial trawl fishery data, even though, for the white grouper for example, traditional fishing is carried over rocky grounds inac- 

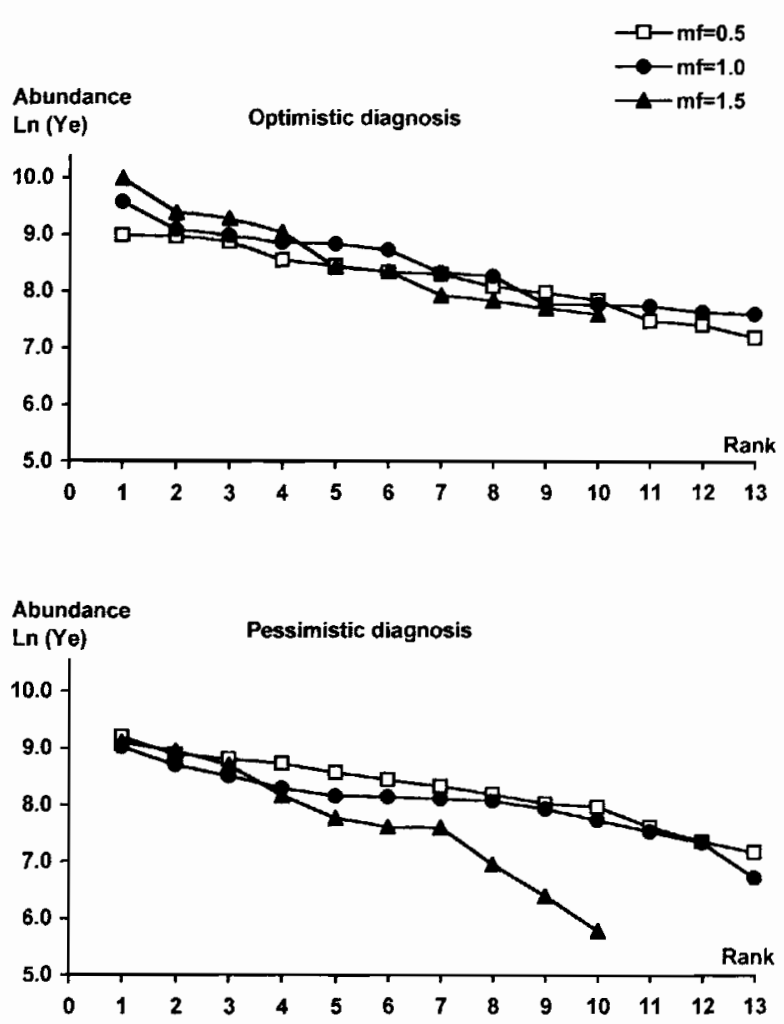

Figure 3. - Rank-ahundance diagrams under optimistic and pessimistic hypothesis for three values of the multiplicator of the 1991 fishing cffort $\left(\ln \left(Y_{e}\right)\right.$ corresponds to the Naperian logarithm of equilibrium yiclds).

cessible to trawlers. Then, calculation of theoretical efforts appear as a stopgap solution in the absence of reliable statistics on the fishing effort deployed by the traditional fleet. That could lead to some strong uncertainties in final diagnosis. Nevertheless, one interest of our study is to try to confine this uncertainty by using two series of effort, one relating to an optimistic hypothesis and the other to a pessimistic one.

However, one can learn from this approach that the harvesting of demersal resources of Senegal has reached a high level during the past few years. As underlined by Laloë (1995), surplus production models should be used in frameworks in order to give representations of fisheries. More than a biological aim, their purpose is to analyze past and present interactions between resources and exploitation, according to the whole reliable data and particularly catches and abundance data. In that way, the multispecific diagnosis, estimated by addition of the monospecific ones, shows a global full-exploitation or an over-exploitation. This result is in agreement with preliminary results presented by Caverivière and Thiam (1994). We have also to note that the most overexploited resources are among the most economically important. Groupers
(Epinephelus sp.), Seabream (Sparus and Dentex sp.), red Pandora (Pagellus bellottii), and Goatfish (Pseudupeneus prayensis) are for example the most targeted species since the 1950s (Garcia et al., 1979). Moreover, this diagnosis seems to be confirmed by the present evolution of the fishery, whose catches are apparently declining for many demersal species (Foucher, pers. comm.).

The calculation of diversity indices and rank-abundance diagrams are based on modelized equilibrium yields with varying fishing effort patterns. The spatiotemporal scale of the studied collection, which does not come from an ecological sampling of the demersal community, is thus theoretical. These indices and diagrams must be detected as abstractions that may be useful when making comparisons of fishing effort patterns. In a fisheries management point of view, the decrease of diversity indices with strong increase of fishing e $\int$ ort could be interpreted as an indicator of a more sensitive fishery, depending on a smaller number of exploited stocks. In an ecological point of view, this result refers to preoccupation on biodiversity in exploited ecosystem.

Obviously, such ecological preoccupations are today more and more present in fisheries science. A general lack of scientific effort may yet be observed concerning fish and fisheries, where fewer contemporary studies focused on biodiversity than on other vertebrate groups (Ryman et al., 1994). The present analysis constitutes a simple first approach in that way. Only some aspects of ecosystem biodiversity and only species level are considered. Neither genetic diversity at a population scale nor functional diversity of ecological communities at the whole ecosystem scale are taken into account. Nevertheless, the level of species diversity is essential and clearly related to the two others (Barbault, 1993). It is generally admitted that it could play an important role for ecosystem resiliency (Lévêque, 1994). For example in the context of African freshwater fisheries, this author (1995) shows that exploitation of highest trophic levels disturbs all trophic relationships as well as the whole ecosystem. At the genetic level, Ryman et al. (1994) underlines that loss of genetic variability within a population may occur through reduced population size; that losses may be substantial also in populations where the number of individuals left is large enough to ignore losses related to inbreeding.

The assessment alone of fishing effect on diversity of the main exploited resources is still insufficient. It may nevertheless constitute a quantitative tool for diagnosis. In our case, past increase of effort did not lead to a decreasing diversity indices. On the other hand, the risk of such a decrease in the case of increasing efforts may be interpreted as a sign of fragility for the exploited ecosystem. In a precautionary approach, such an index must be seriously considered. 


\section{Acknowledgment}

We would like to thank sincerely all technicians and scientists of the CRODT who have contributed to the constitution of the data base used in this study; $A$. Caverivière and $M$. Thiam have played a particularly important role in the estimation of fisheries statistics. We are also grateful to J.C. Brêthes and to anonymous referees for their helpful comments.

\section{REFERENCES}

Barbault R. 1992. Ecologic des peuplements, structure, dynamique et évolution. Masson, Paris, $273 \mathrm{p}$.

Barbault R. 1993. Une approche ćcologique de la biodiversité. Nature Sciences Siciétés 1, 322-329.

Barry-Gérard M., T. Diouf, A. Fonteneau 1994. L'évaluation des ressources exploitables par la pêche artisanale sénégalaise. Tome 1. Compte rendu des discussions et des conclusions (en français et en anglais). Colloques et Séminaires, ORSTOM éds. Paris, 98 p.

Caverivière A., M. Thiam 1994. Essai d'application d'un modèle global à l'ensemble des espèces démersales côtières du Sénégal. In: L'évaluation des ressources cxploitables par la pêche artisanale sénégalaise, Tome 2, Barry-Gérard M., T. Diouf, A. Fonteneau éds. Colloques et Séminaires, ORSTOM éds. Paris, 323-332.

Diallo M. 1994. Quelques éléments sur la compétition des pêcheries artisanales et industrielles pour l'accès au Sénégal. In: L'évaluation des ressources exploitables par la pêche artisanale sénégalaise, Tome 2. Barry-Gérard M., T. Diouf, A. Fonteneau éds. Colloques et Séminaires, ORSTOM ćds. Paris, 351-352.

Fonteneau A. 1994. La compétition entre pêche industrielle et pêche artisanales : quelques réflexions sur la problématique des analyses. In: L'évaluation des ressources exploitables par la pêche artisanale sénégalaise, Tome 2. BarryGérard M., T. Dioui, A. Fonteneau éds. Colloques et Séminaires, ORSTOM éds. Paris, 339-349.

Fox W.W. 1970. An exponential surplus-yield model for optimizing exploited fish populations. Trans Am. Fish. Soc. 99, 80-88.

Fox W.W. 1975. Fitting the generalized stock production model by least-squares and equilibrium approximations. U.S. Fish Bull. 73, 23-37.

Fréon P., C. Mullon, G. Pichon 1993. CLIMPROD: Experimental interactive software for choosing and fitting surplus production models including environmental variables. FAO, Rome, Computerized Information Series (Fisheries), $5,76 \mathrm{p}$.

Frontier S. 1976. Utilisation des diagrammes rangsfréquences dans l'analyse des écosystèmes. Bull. Ecol. 8, 445-464.

Fronticr S. 1983. L'échantillonnage de la diversité spécifique. In: Stratégic d'échantillonnage en écologie. S. Frontier éd. Masson, Paris, 416-436.

Garcia S., F. Lhomme, J. Chabanne, C. Franqueville 1979. La pêche démersale au Sénégal : historique et potentiel. COPACE Sér. 78, 59-77.
Gascuel D. 1994a. Evaluation sommaire des ressources exploitées par la pêche artisanale sénégalaise. Rapp. Unité Halieutique de l'ENSAR, Rennes, 80) p.

Gascuel D. 1994b. Modélisation de la dynamique des stocks exploités par la pêche artisanale sénégalaise : intérêt, limites et contraintes de l'approche structurale. In: L'évaluation des ressources exploitables par la pêche artisanale sénégalaise, Tome 2. Barry-Gérard M., T. Diouf, A. Fonteneau éds. Colloques et Séminaires, ORSTOM éds. Paris, 385-403.

Gascuel D., M. Thiam 1994. Evolution de l'abondance des ressources démersales sénégalaises : estimation par modélisation linéaire des PUE. In: L'évaluation des ressources exploitables par la pêche artisanale sénégalaise, Tome 2. Barry-Gérard M., T. Diouf, A. Fonteneau éds. Colloques et Séminaires, ORSTOM éds. Paris, 191-214.

Lalö̈ F. 1995. Should surplus production models be fishery description tools rather than biological models? Aquat. Living Resour. 8, 1-12.

Laloë F., A. Samba 1991. A simulation model of artisanal fisheries of Senegal. ICES Mar. Symp. 193, 281-286.

Lévêque C. 1994. Le concept de biodiversité : de nouveaux regards sur la nature. Nature Sciences Sociétés 2, 243-254.

Lévêque C. 1995. Rolc and consequence of fish diversity in the functioning of African freshwater ecosystem : a review. Aquat. Living Resour. 8, 59-78.

Maury O. 1994. Méthodologie d'étude structurale de la dynamique des stocks exploités par la pêche artisanal sénégalaise, application à l'exploitation du pageot Pagellus bellottii. Rapp. DAA Unité Halieutique de I'ENSAR, Rennes, $87 \mathrm{p}$.

Pella J.J., P.K. Tomlinson 1969. A generalized stock production model. Bull. Inter-Am. Trop. Tuna Comm. 13, 421-458.

Ryman N., F. Utter, L. Laikre 1994. Protection of aquatic biodiversity. In: The state of the world's fisheries resources. Proc. World Fisheries Congress, Plenary Sessions. C.W. Voigtlander ed. Oxford and IBH Publishing Co. New Delhi, 92-115.

Samba A. 1994. Présentation sommaire des différentes pêcheries sénégalaises. In: L’évaluation des ressources exploitables par la pêche artisanale sénégalaise, Tome 2, Barry-Gérard M., T. Diouf, A. Fonteneau éds. Colloques et Séminaires, ORSTOM éds. Paris, 1-9.

Schaefer M.B. 1954. Some aspects of the dynamics of populations important to the management of the commercial marine fisheries. Bull. Inter-Am. Trop. Tuna Comm. 1, 25-56.

Shannon C.E. 1948. A mathematical theory for communications. Bell. Syst. Techn. J. 27, 379-423 \& 623-656. 